\title{
GENERAL LAWS OF COMPETITION DUEL AND UNIVERSAL REQUIREMENTS TO TECHNICAL-TACTIC FITNESS OF ELITE WRESTLERS
}

Korobeynikov G.V. ${ }^{1}$, Latyshev S. V. ${ }^{2}$, Latyshev N.V. ${ }^{3}$, Korobeynikova L.G. ${ }^{1}$, Goraschenko A.U. ${ }^{4}$

${ }^{1}$ National University of Physical Education and Sport of Ukraine

${ }^{2}$ Rostov State University of Civil Engineering

${ }^{3}$ Donetsk National University

${ }^{4}$ State University of Physical Education and Sport the Republic of Moldova

\begin{abstract}
Purpose: to determine and formulate general technical-tactic laws (rules) of competition duel in modern free style wrestling. Material: competition functioning of free style wrestlers at Olympic Games has been analyzed. Results of authors' own pedagogic observations and advanced experience of free style wrestling specialists have been generalized. Results: it was found that victory in duel can be resulted only from attacking tactic of duel. It was determined that wrestlers' activity (quantity of actual attacks in unit of time) varies from 1 to 2.2 attacks per minute. Reliability of attack (ratio of quantity of assessed attacks to quantity of actually fulfilled attacks) is within $0.33-0.63$. Reliability of defense (ratio of quantity of successfully repelled opponent's attacks to general quantity of his actual attacks) is from 0.55-0.78. Efficiency of fighting in stance is within 0.6-1.3 points per minute. Efficiency of ground fighting is 1.3-2.3 points per minute. Conclusions: coach shall bring the formulated laws in compliance with specificity of his functioning and consider them, when planning training process of junior wrestlers.
\end{abstract}

Key words: wrestling, competition, laws, technique, tactic.

\section{Introduction}

In modern sports, only talented sportsman can achieve high international results. His talents, abilities and characteristics shall adequately correspond to requirements of modern competition functioning in the chosen kind of sports [7 - 10, 14, 15].

This statement is true for all kinds of sports. For martial arts, its interpretation and practical realization have significant specificity. It is connected with the fact that genotype predisposition to martial arts is conditioned by sportsman's bents and systemic interconnection of practically all qualities (characteristics): anthropometrical, physical, psychic, social-psychological [7 - 9, 12, 13

With it, compensatory factor is rather substantial in sport wrestling, when some qualities can be compensated by other $[7-9,12,15]$. For example, deficit of strength can be compensated by high endurance or coordination and flexibility. It forms its individual style of combat, its peculiar technique. With it, level of separate motor qualities can substantially differ in wrestlers of close sportsmanship but different combat styles [7, 12, and $13]$.

Combat style is determined by dominantly expressed development of one or several motor qualities in combination with relevant features of sportsman's body composition and psyche. Every elite wrestler conducts successful duels strictly as per his own (individual) combat style (which is, as a rule, typical). It is the basis of his successful competition functioning [5 - 7]. Every typical combat style has its own features of competition technique and combat tactic [6 - 8].

Generalization of coaches' experience and results of competition functioning show that it is possible to outline the most general laws (rules) of competition duel's conduct. They are intrinsic to all elite wrestlers, independent on weight category or combat style in free style wrestling. These laws condition certain universal (for all elite wrestlers) requirements to technical-tactic fitness.

To large extent, coaches rely on their experience and do not consider universal requirements of technicaltactic training. Coaches often make mistakes in sequence of mastering and in accentuation of attention in process of technical-tactic training. In the whole, it is connected with coach's not systemic choice of trainings' content at stage of basic training. It often results in great losses in wrestler's sports functioning.

(c) Korobeynikov G.V., Latyshev S. V., Latyshev N.V.,

Goraschenko A.U., Korobeynikova L.G., 2015

doi:10.15561/20755279.2015.0605 
For optimization of trainings, coach shall clearly and definitely understand general laws, consequences of which determine methodic and practical aspects of technical-tactic training. They shall be considered by coach when making working programs and correcting of junior wrestlers' training. These facts condition the importance of our work.

Purpose, tasks of the work, material and methods

The purpose of the work is to determine general technical-tactic laws (rules) of competition duel in modern free style wrestling as well as to formulate universal requirements to wrestler's technical-tactic fitness.

Materials and methods of the research: generalization of results of analysis of scientific-methodic literature, pedagogic observations, video-analysis of competition duels and specialists' advanced experience.

\section{Results of the research}

We have analyzed competition functioning of free style wrestlers at Olympic Games [2 - 4, 11]. Besides, we generalized results of own pedagogic observations and advanced experience of free style wrestling specialists $[1,7-9,12,13]$. It permitted to outline general laws of competition duel's conduct and present some universal principles of elite wrestlers' technical - tactic fitness. Below we give these laws and principles (requirements).

\section{Wrestling stance}

Stance is main position in initial period of contact with opponent, when wrestler touches mat only by feet. Adequacy (correctness) of wrestling stance is initial condition of combat effectiveness and of duel in general. Elite wrestler conduct duels in reliable for defense and convenient for attack wrestling stance. Such stance can be called "correct" and adequate to combat conditions.

"Correct" wrestling stance implies steady wrestler's position under external impacts imposed by opponent. It shall permit easy maneuvering and quick transition to attack, defense or counter-attack. It is achieved at the account of wrestler's body weight uniform distribution on all foot and proper position of legs and torso.

Usually wrestler's feet are located at one and half shoulder width. With it one foot (by half of its length) is in front of the other. It ensures required (reliable) stability when opponent tries to imbalance wrestler forwardbackward or to the right-to the left. Legs shall be compulsory bent a little in knees (with angle between ankle and hip of about $150-165^{\circ}$ ) and relaxed for timely attacks and defenses.

Torso shall be bent in respect to the line of horizon. It ensures defense of legs against opponent's attacks and prevents from headlock or capture of arm by opponent. Angle of torso bent shall be kept during all duel period in spite of increasing fatigue. The value of angle is chosen, considering wrestler's anthropometric characteristics.

Arms shall be bent in elbows (approximately by $90^{\circ}$ ) and their projection on mat shall be approximately by length of hand in front of shoes' toes.

Specific features of wrestling stance and other technical and tactic actions on next stages of training are conditioned by choice of own individual combat style.

\section{Distance}

Distance of combat is chosen depending on combat style and for increasing convenience of duel conduct.

\section{Moving on mat}

Moving on mat is directed at seeking favorable moment for attack or advantageous position in respect to opponent. Elite wrestler usually moves forward, to the right or to the left in competition duel He tries to "press" opponent constantly with speed-power actions, with false attacks. With it, the main thing is to keep "correct" stance. Backing shall be excluded.

The mentioned law is realized in combat on the base of several requirements (conditions). When backing, it is practically impossible to fulfill efficient attack with face directed forward. Backing is punished by referees. If wrestler makes his opponent to back, he deprives him of possibility to attack. Active moving and onset ensure also psychological confidence in success of combat and initiative. It is especially important when equal by sportsmanship wrestlers are fighting.

\section{Grasp}

Grasp implies strong connection with body part of opponent or parts of own body for fulfillment of technique action or blocking of opponent's action. Fight for "own" grasp and its hold are important components of duel. They can serve as parameters of competition functioning simulation. In such case time of being in own grasp is proportional to probability of actual attack and saving advantages. Since the first seconds of combat 
successful wrestler tries to fulfill (to impose) own grasp. Grasp can be attacking (as a rule) and blocking. In such grasp opponent can not fulfill attack. He must impose his own grasp. It requires additional efforts.

In general case ( $60 \%$ of time sportsman is in his own grasp and $40 \%$ - in opponent's grasp) wrestler has 1.5 times more opportunities to execute attack and not to admit opponent' attack.

\section{Attacking actions}

Attacking actions are the basis of attacking strategy. It is a determining one in building of modern duel in free style wrestling. Attack consists of various preparatory actions and attacking technique (resulting part). Means of technical tactic preparation for technique's fulfillment are rather various. With it, techniques have rather stable space time and power structure. Preparation for technique's fulfillment is directed to distraction of opponent's attention from actual attack. Elite wrestler shall have in his arsenal minimum 2-3 (better 3-4) main technical-tactic actions (TTA) for fighting in stance. With it, these TTA shall be selected so that wrestler should be able to attack opponent from the right and from the left. This condition is compulsory, when selecting attacking TTA for their perfection. Junior wrestler will never become elite sportsman, if he can fulfill attacks only from one side. For elite wrestler it is very easy to defend reliably one side.

It is desirable for wrestler to have in arsenal of main techniques minimum one throw. It can be applied at the beginning of combat, when opponent is not too sweaty and grasp can be fulfilled reliably. Thus, it is possible to receive significant advantage. Throw also can be applied at the end of fight, when fight result can not be saved by one or two points and it is necessary to risk and fulfill throw.

For ground fighting sportsman shall be able to fulfill minimum one (better two-three) main techniques, connected with each other. There are some elite sportsmen (Olympic champions), who do not fulfill any TTA in ground fighting. But it is an exclusion from the rules.

Elite wrestler shall be able to fulfill main techniques in fight with any opponent of his weight category minimum 1-2 times.

\section{Defense actions}

Defense actions are the main confusing factor, hindering opponent's TTA. With active usage of own body parts, in defense wrestler destroys opponent's attack and tries to quickly create convenient situation for counter attack.

Characteristic (distinctive) feature of elite wrestlers is psycho-physiological ability to fight to the end. Analysis of competition functioning and accumulated experience shows that even in completely losing positions elite wrestlers do not lose points and even can win. It is explained by the fact that in fight for points sportsmen are in state of maximal physical and psychic-emotional tension. Sportsmen spend forces very quickly. That is why, in such conditions opponent can simply feel lack of forces for efficient completion of TTA or he can make mistake, caused by fatigue.

In ground fighting reliability of elite wrestlers' defense is ensured practically by $100 \%$. Losing of points by elite wrestler in ground fighting is connected with occasional factors. Such high reliability of defense is conditioned by the fact that defense requires much less efforts. That is why it is much easier not to lose points (i.e. neutralize opponent's efforts) than to win points (i.e. to create favorable conditions for attack and fulfill it).

\section{Counter attacking actions}

Counter attacking actions are responding TTA after organization of defensive actions or for anticipation of opponent's attack. Success of counter attacking actions is ensured by high quickness and coordination.

Elite wrestler shall have carefully trained technique of responsive attack in response to opponent's attack by legs. Responsive attacks (as system of counter attacking actions) can be conventionally divided into three groups, depending on how quickly the attacked wrestler responds to attack; in which phase of attack he meets the opponent.

First group - the attacked wrestler responds practically immediately. He fulfills counter movement, followed by overturn by twisting. Second group - the attacked wrestler responds a little later and, having met the opponent, he fulfills attack to legs (to the nearest leg of opponent). Third group - the attacked wrestler responds too late and responsive attack implies positioning behind the opponent. 


\section{Fighting in "standard" positions}

In every fight wrestlers get in some, rather definite positions, for several times. These typical positions are called "standard". In such standard positions wrestler shall be able to fight as per perfectly trained patterns. Let us regard two standard positions, which are met very often.

The first position appears, when wrestler grasped leg and did not manage to finish technique (because of opponent's timely defense). In $80 \%$ elite wrestler brings fulfillment of this TTA to referee's assessment. The second position is grasping of head and shoulder. It appears, when wrestler tries to attack opponent's legs, but the opponent timely responds (does not permit for attacking wrestler to grasp legs). In this position attacking wrestler shall be able to realize reliable (practically in $100 \%$ of cases) defense. Wrestling in the mentioned positions shall be paid special attention to, when planning training of junior wrestlers.

\section{Stance-ground fighting}

Fight is started in stance. Since the first seconds fight is directed to move opponent into ground fighting. With moving opponent into ground fighting, attacking wrestler always strives to fulfill technique in ground fighting, when opponent is not ready for defense.

Elite wrestler shall compulsory have this skill. We give two the most effective transitions from stance fighting to ground fighting as examples: 1 - attack of legs with head being outside, then transition to overturn; 2 - attack of legs with head being inside, then transition to overturn by twisting with cross grasp of shins.

\section{Discussion}

As analysis of competition functioning shows $[2-4,11]$ as well as experience of advanced specialists in sport wrestling $[1,7-9,12,13]$ only attacking tactic can result in victory. Defensive fighting is not intrinsic to elite wrestlers. It is acceptable only for preservation of score. In most cases in fighting, wrestler combines different kinds of tactic, depending on certain tasks, which he solves in definite moment of time. With it elite wrestler keeps mainly attacking tactic in competition duel.

For realization of attacking tactic wrestler shall meet the mentioned above 9 requirements. These results confirm and supplement the researches of other authors. For example, authors $[12,14]$ pay special attention to formation of "correct" stance. It is the basis of effective competition functioning.

In works $[13,15]$ authors accentuate attention on variability of preparatory actions and rather rigid structure of main technique of elite wrestler. It is confirmed by item 5 of our results.

Results, received in items 6, 7, 8, 9 supplement researches of authors $[1,8,9,12,13,15]$. These data characterize distinctive features of elite wrestlers: ability to fight to the end (for points); having perfect responsive attacking techniques; ability to fight in standard positions; ability to realize transition from stance to ground fighting without pauses.

Training of elite wrestlers requires strict individualization $[5,6,10$, and 11]. Depending on style of combat, wrestler chooses the following: attacking and blocking grasps; distance of duel conduct; directions of moving on mat. With it, in choice there are general patterns, intrinsic to all elite wrestlers. They are presented in items 2, 3, 4 of our results.

Attacking style of duel conduct is intrinsic to all elite wrestlers. However, quantitative characteristics of competition functioning substantially depend on combat style. Analysis [2 - 4, 11] of wrestlers' competition functioning at Olympic Games shows that activity (quantity of actual attacks per unit of time) of wrestlers (who won 1-5 places) varies from 1 to 2.2 attacks per minute. Reliability of attack (ratio of assessed attacks to quantity of actually fulfilled attacks) is within 0.33-0.63. Reliability of defense (ratio of quantity of successfully repelled attacks to total quantity of actual attacks) is within $0.55-0.78$. Efficiency of fighting in stance is within $0.6-1.3$ points per minute. Efficiency of ground fighting is 1.3-2.3 points per minute.

Generalizing these data we can affirm that in stance fighting elite wrestler shall fulfill in average 4-5 actual attempts to fulfill technique. In this case every second-third attempt shall result in good points. Ground fighting is approximately two times more efficient than fight in stance. The formulated above regularities shall be complied by coach with specificity of his functioning and considered when planning training process of junior wrestlers. 


\section{Conclusions}

On the base of analysis of competition functioning and generalization of experience of advanced specialists in sport wrestling we found and formulated general laws of competition duel conduct in modern free style wrestling. On this ground we presented universal peculiarities and requirements to technical-tactic fitness of elite wrestlers.

The prospects of further researches: the received results can be regarded as the basis for further profound analysis of competition functioning as well as for further specification and correction of working training programs at stages of basic training. It is anticipated development of definite training tasks on technical tactic and on special physical fitness.

\section{Conflict of interests}

The authors declare that there is no conflict of interests.

\section{References}

1. Korobeynikov GV, Radchenko UA. Osoblivosti tekhnichnoi pidgotovlenosti borciv greko-rims'kogo stiliu visokoi kvalifikacii [Specific features of technical fitness of Greco-Roman elite wrestlers]. Pedagogics, psychology, medical-biological problems of physical training and sports, 2009;7:81-85. (in Russian)

2. Latishev NV, Latishev SV, Gavrilin VA. Analiz sorevnovatel'noj deiatel'nosti finalistov igr XXIX Olimpiady V Pekine po vol'noj bor'be [Analysis of competition functioning of free style wrestlers-finalists of 29th Olympic Games]. Teoriia i metodika fizichnogo vikhovannia, 2008;1:173-180. (in Russian)

3. Latishev SV. Analiz taktiko-tekhnichnikh dij borciv vil'nogo stiliu na Igrakh XXVI Olimpiadi v Atlanti [Analysis of technical-tactic actions of free style wrestlers at 26th Olympic Games in Atlanta]. Teoriia $i$ metodika fizichnogo vikhovannia i sportu, 2000;2-3:20-23. (in Ukrainian)

4. Latishev SV, Gromakov AU, Chocharay ZU. Sravnitel'nyj analiz kharakteristik sorevnovatel'noj deiatel'nosti borcov vol'nogo stilia na Olimpijskikh igrakh v Atlante i Sidnee [Comparative analysis of competition functioning characteristics of free style wrestlers at Olympic Games in Atlanta and Sydney]. Pedagogics, psychology, medical-biological problems of physical training and sports, 2001;2:45-52. (in Russian)

5. Latishev SV. Stili protivoborstva v sovremennoj vol'noj bor'be [Combat styles in modern free style wrestling]. Fizichne vikhovannia, sport i kul'tura zdorov'ia u suchasnomu suspil'stvi, 2011;1:69-73. (in Russian)

6. Latyshev S, Korobeynikov G, Korobeinikova L. Individualization of training in wrestlers. International Journal of Wrestling Science, 2014;4(2):28-33.

7. Latyshev SV. Kolichestvennaia ocenka kharakteristik uspeshnosti vedeniia poedinka dlia sportsmenov $\mathrm{S}$ razlichnymi stiliami protivoborstva $\mathrm{v}$ vol'noj bor'be [Quantitative assessment of characteristics of duel's success for different combat styles' wrestlers in free style wrestling], Moloda sportivna nauka Ukraini, 2011;15(1):168-174. (in Ukrainian)

8. Novikov AA. Osnovy sportivnogo masterstva [Principles of sportsmanship], Moscow: Soviet sport; 2012. (in Russian)

9. Piloyan RM. Uzlovye voprosy mnogoletnej podgotovki borcov [Key issues of many years' training of wrestlers], Moscow: MOGIFK; 1988. (in Russian)

10. Platonov VN. Sistema podgotovki sportsmenov v olimpijskom sporte [The system of preparation of sportsmen in Olympic sport], Kiev: Olympic Literature; 2004. (in Russian)

11. Podlivaev BA, Korzhenevsky A. Variation of the performance in qualified wrestlers in Greco-Roman wrestling by their level of functional skills. International Journal of Wrestling Science, 2013;3(2):14 - 21.

12. Tumanian GS. Strategiia podgotovki chempionov [Strategy of champions' training], Moscow: Soviet sport; 2006. (in Russian)

13. Shahmuradov UA. Vol'naia bor'ba [Free style wrestling], Moscow: High school; 1997. (in Russian)

14. Emma Sandberg, Natha T. Bell. Coaching Youth Wrestling. Illinois: Human Kinetics; 2007.

15. Ryan T, Sampson J. Elite Wrestling. New York: McGraw-Hill; 2006.

16. Korobeynikov G, Mazmanian K, Korobeynikova L, \& Jagiełło W. Psychophysiological states and motivation in elite judokas. Archives of Budo, 2010;6(3):129-136. 
17. Korobeynikov GV, Radchenko YA. Demonstration of intuitive thinking in conditions of competitive activity depending on athletes' psychophysiological state. Pedagogics, psychology, medical-biological problems of physical training and sports, 2012;6:87-91.

18. Korobeynikova LG. Determinant of psychophysiological state of sportsmen of high qualification with different emotional characteristics. Pedagogics, psychology, medical-biological problems of physical training and sports, 2011;4:94-97.

19. Latyshev SV, Korobeynikov GV. Approach of the systems to problem of individualization of training of fighters. Physical Education of Students, 2013;5:65-68. http://dx.doi.org/10.6084/m9.figshare.771109

20. Zapovitriana EB, Korobeynikov GV, Korobeinikova LG. Peculiarities of vegetative regulation of heart rate in wrestlers of different age groups. Pedagogics, psychology, medical-biological problems of physical training and sports, 2015;4:22-26. http://dx.doi.org/10.15561/18189172.2015.0404

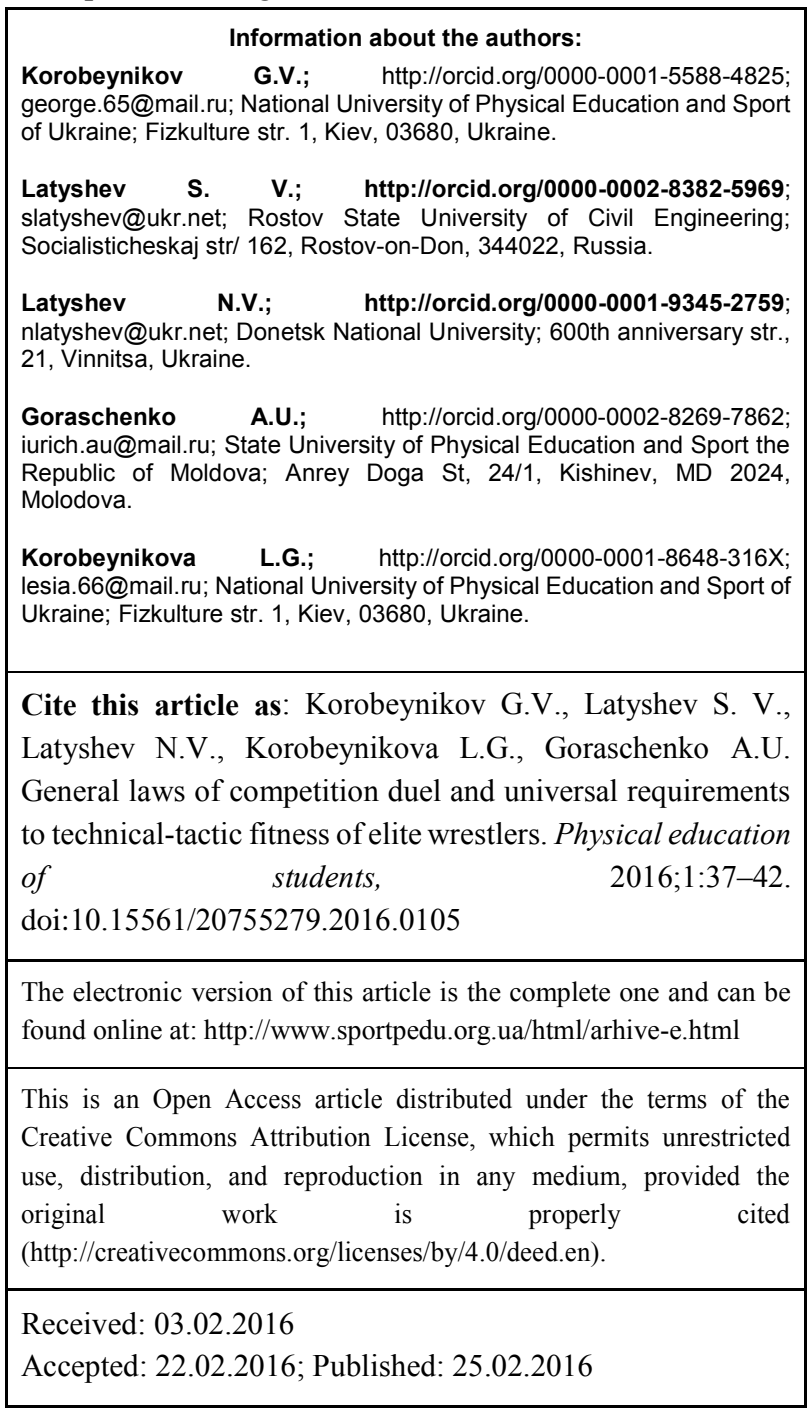

